Список використаних джерел

1. Бабенко О.О. Таран M.L. Теоретичний аналіз вивчення страху як психологічної проблеми у формуванні самооцінки підлітків. Науковий вісник Херсонського державного університету. Серія: Психологічні науки. $-2016,2$ (2). - С. 12-15

2. Живанова В. А. Дослідження страху як психологічного феномену в історичній ретроспективі. Вісник Національного технічного університету України Київський політехнічний інститут. Філософія. Психологія. Педагогіка. - 2010, 3. - С. 121-125.

3. Мовчан М.М. Феномен страху: його класифікація і рівні. Наукові записки [Національного університету Острозька академія]. Сер.: Філософія. - 2012, 10. - С. 197-204.

4. Мовчан М. М. Рівні страху і фобія: філософський аналіз. Філософські обрії. - 2015, 33. - С. 118-125.

5. Ольховецький С. М. Феноменологіс тривоги та страху. Проблеми сучасної психології. - 2010. - С. 9.

6. Сидоренко Ж.В., Недбалюк О.О. Проблемні аспекти самоставлення особистості в юнацькому віці. Науковий вісник Херсонського державного університету. Серія "Психологічні науки". - 2018, 1.1. - С. 163-168.

7. Ставицька С.О. Соціально-психологічні особливості реалізації потреби в саморозвитку, самооцінки життєвих цілей та самоставлення як компонентів розвитку самосвідомості в юнацькому віці. Проблеми сучасної психології. - 2014. - С. 23.

8. Царькова О.В., Радченко С.В. Теоретичні аспекти прояву психологічного феномену тривожності. Актуальні проблеми психології. - 2015, 7, Вип. 38. - С. 479-491.

9. Яворська-Вєтрова І.В. Теоретичний аналіз проблеми самоставлення: ціннісний аспект. Актуальні проблеми психології. - 2017, 13.6. - С. 198-206.
References

1. Babenko O.O., Taran M.I. Teoretychnyi analiz vyvchennia strakhu yak psykholohichnoi problemy u formuvanni samootsinky pidlitkiv. Naukovyi visnyk Khersonskoho derzhavnoho universytetu. Seriia: Psykholohichni nauky, 2016, 2 (2): S. 12-15

2. Zhyvanova V. A. Doslidzhennia strakhu yak psykholohichnoho fenomenu $v$ istorychnii retrospektyvi. Visnyk Natsionalnoho tekhnichnoho universytetu Ukrainy Kyivskyi politekhnichnyi instytut. Filosofiia universytetu Ukrainy Kyivskyi politekhnich
Psykholohiia. Pedahohika, 2010, 3: S. 121-125

3. Movchan M.M. Fenomen strakhu: yoho klasyfikatsiia i rivni. Naukovi zapysky [Natsionalnoho universytetu Ostrozka akademiia]. Ser.: Filosofiia, 2012, 10: S. 197-204.

4. Movchan M. M. Rivni ctrakhu i fobiia: filosofskyi analiz. Filosofski obrii, 2015, 33: S. 118-125.

5. Olkhovetskyi S. M. Fenomenolohis tryvohy ta strakhu. Problemy suchasnoi psykholohii, 2010, S. 9

6. Sydorenko Zh.V., Nedbaliuk O.O. Problemni aspekty samostavlennia osobystosti v yunatskomu vitsi. Naukovyi visnyk Khersonskoho derzhavnoho universytetu. Seriia "Psykholohichni nauky", 2018, 1.1: S. 163-168.

7. Stavytska S.O. Sotsialno-psykholohichni osoblyvosti realizatsii potreby $v$ samorozvytku, samootsinky zhyttievykh tsilei ta samostavlennia yak komponentiv rozvytku samosvidomosti $v$ yunatskomu vitsi. Problemy suchasnoi psykholohii, 2014, S. 23.

8. Tsarkova O.V., Radchenko S.V. Teoretychni aspekty proiavu psykholohichnoho fenomenu tryvozhnosti. Aktualni problemy psykholohii, 2015, 7, Vyp. 38: S. 479-491.

9. lavorska-Vietrova I.V. Teoretychnyi analiz problemy samostavlennia: tsinnisnyi aspekt. Aktualni problemy psykholohii, 2017, 13.6: S. 198-206.

Надійшла до редколегії 27.09.20 Рекомендована до друку 28.10.20

Larysa Terletska, PhD (Psychology), Associate Prof.,

Iryna Kukhar, Master Student

Taras Shevchenko National University of Kyiv, Kyiv, Ukraine

\title{
THE RELATIONSHIPS BETWEEN FEARS, PHOBIAS, ANXIETY ON SELF-IDENTITY
}

According to the aim (to identify the features of the connection of fears, phobias, anxiety with self-esteem of adolescence), an empirical study was conducted, in which the respondents were representatives of school and student youth, namely 120 people: 60 students of 10-11 grades (15-17 years) of Vyshhorod comprehensive school №2 and №3. This sample was chosen not by chance. After all, it is in adolescence is the active development and formation of all components of self-awareness, including self-esteem. According to the age periodization of M. Savchyn and L. Vasylenko, adolescence is divided into two groups: representatives of early youth (15-18 years) and late youth (18-23 years) or senior school and student age.

The presented study covers only certain aspects of such a complex phenomenon as self-assessment. As its subject was the sociopsychological features of self-attitude of adolescents and young people, other social and age categories, as well as socio-psychological factors influencing the features of self-attitude, in particular: financial status, degree of self-realization and more.

The study of this problem requires further comprehensive research, because adequate positive self-attitude is the most optimal for the formation and development of personality, determines the achievement of its inner harmony.

In our further study of self-assessment, a promising direction, in our opinion, is to clarify the features of this phenomenon in other age groups. Consideration of the influence of gender on the peculiarities of self-assessment, in this perspective, will be useful in both theoretical and practical aspects.

Keywords: fears, phobias, anxiety, emotions, self-assessment, personality.

Bulletin of Taras Shevchenko National University of Kyiv. Series "Psychology". № 1(11), pp. 63-70 (2020) УДК 159.923

DOI: https://doi.org/10.17721/BSP.2020.1(11).12

\section{ISSN 1728-3817}

(C) Taras Shevchenko National University of Kyiv,

Publishing and Polygraphic Center "Kyiv University", 2020

Світлана Чуніхіна, канд. психол. наук, ст. наук. співроб. Інституту соціальної та політичної психології НАПн України, Київ, Україна ORCID ID 0000-0002-0813-6741

\section{СУСПІЛЬНЕ СТАВЛЕННЯ ДО ОСВІТНІХ РЕФОРМ: ДОСЛІДЖЕННЯ ПРОБЛЕМИ ВІДКРИТОСТІ СУДЖЕНЬ (OPEN-MINDEDNESS)}

У статmі розглянуто проблему суперечливого ставлення громадськості до освітніх реформ у зв'язку із феноменом відкритості суджень (ореп-mindedness). На основі огляду тематичних досліджень виокремлено два великих напрями концептулізації відкритості суджень. Перший напрям вивчає відкритість суджень у контексті міжособистісної взаємодії - як відсутність упереджень по відношенню до представників груп, які інтерпретуються як "інші", готовність толерувати "інакшість" та продуктивно взаємодіяти з іншими людьми в умовах конфлікту думок та позицій. у другому напрямі відкритість суджень розглядається передусім як когнітивна налаштованість на сприймання нових ідей, толерування розмаїття думок та готовність мислити поза встановленими межами ("оut оf bох"). На вибірці з 230 респондентів досліджено зв'язок когнітивного (догматизм) та особистісного (відкритість новому досвіду) аспектів відкритості суджень із суб'єктивним ставленням до освітніх реформ. Показано, що догматизм більше пов'язаний з категоричністю суджень щодо освітніх реформ. Більш догматичні респоденти схиляються до негативних оцінок реформ, мени догматичні скоріше не мають усталених оціночних суджень. Відкритість новому досвіду визначає скоріше модальність оцінок освітніх реформ. більш "відкриті" респонденти схильні в цілому позитивніше оцінювати зміни, що відбуваються внаслідок реформ, ніж менш "відкриті", яким притаманний певний песимізм. З'ясовано, що догматизм і відкритість новому досвіду по-різному проявляють себе у ставленні до освітніх реформ серед професіоналів, зайнятих в освітній сфері, і професійно не пов'язаних $з$ освітою респондентів.

Ключові слова: відкритість суджень, догматизм, відкритість новому досвіду, суспільне ставлення, освітня реформа

В українському суспільстві сфрормувався сталий консенсус щодо необхідності реформування вітчизняної системи освіти [3]. За даними всеукраїнських репре- зентативних опитувань, що проводяться Інститутом соціальної та політичної психології НАПН України в рамках моніторингу громадської думки щодо проблем 
освіти та заходів з ії реформування, станом на вересень 2020 року практично дві третини громадян (64,6\%) прагнуть освітніх реформ. Втім, підтримуючи реформи в цілому, громадяни часто не підтримують або навіть чинять опір конкретним змінам, які безпосередньо впливають на умови їхнього життя, професійної діяльності тощо. Зокрема, на момент останнього опитування лише близько чверті респондентів $(26,4 \%)$ повідомили про схвальне ставлення до напряму, в якому наразі розвивається вітчизняна освіта. Найменш популярним аспектом освітніх реформ у суспільстві залишається перехід на 12-річне шкільне навчання: тільки кожна шоста особа висловлює позитивне ставлення до цього нововведення, у той час, як майже дві третини респондентів $(65,1 \%)$ налаштовані негативно.

Однією з причин подібного ставлення суспільства до освітніх рефрорм $€$ недостатня поінформованість: понад половину (59,3\%) респондентів вказують на дефіцит інформації про заплановані та вже реалізовані реформи. Однак навіть серед найкраще поінформованих верств населення, зокрема працівників освіти, залишається чимала кількість тих, хто готовий пручатися інноваціям в освіті. Відтак, необхідно продовжувати досліджувати психологічні чинники, що сприяють, або навпаки, заважають формуванню позитивної громадської думки до освітніх інновацій, без чого запровадження цих інновації буде значно менш успішним та ефективним.

Відкритість суджень (open-mindedness) як чинник психологічної готовності до освітніх реформ

У психологічній думці концепт відкритості суджень (open-mindedness) почав розвиватися з 30-х років минулого сторіччя у дослідженнях Джона Дьюї. Цей розвиток зазнав кілька хвиль актуалізації - у 60-х, 80-х, 90х роках та на початку XXI ст. [15]. Наразі ссрормувалися два великих напрями концептуалізації поняття відкритості суджень та дослідження ії̈ проявів у різних сфрерах суспільного життя. Перший напрям вивчає відкритість суджень у контексті міжособистісної взаємодії - як відсутність упереджень по відношенню до представників груп, які інтерпретуються як "інші", готовність толерувати "інакшість" та продуктивно взаємодіяти з іншими людьми в умовах конфллікту думок та позицій. У другому напрямі відкритість суджень розглядається передусім як когнітивна налаштованість на сприймання нових ідей, толерування розмаїття думок та готовність мислити поза встановленими межами ("out of box"). Розглянемо детальніше кожен з цих напрямів.

1. Особистісна відкритість

В середині $\mathrm{XX}$ ст. популярним дослідницьким напрямом було вивчення впливу відкритості суджень щодо інших людей на точність соціальної перцепції. Хоча гіпотеза, згідно з якою більш відкрито налаштовані люди здатні точніше та повніше характеризувати інших, не знайшла експериментального підтвердження, було прийнято висновок, що відкритість у цілому передбачає приязне ставлення до інших людей і сприяє більш повному усвідомленню дійсності. Тобто відкриті індивіди здатні сприймати об'єктивну реальність та кожну нову людину такими, якими вони, не намагаючись втиснути це сприймання у рамки суб'єктивних переконань, настановлень та стереотипних зразків [17].

Дін Тйосволд і Маргарет Пун зосередили свою увагу на проявах особистої відкритості у корпоративній взаємодії, у тому числі у вирішенні корпоративних конфліктів. Вони показують, що конфлікти, сфокусовані на цілях, фрормують необхідний контекст для взаємодії на засадах відкритості суджень, на відміну від конфоліктів, сфокусованих на взаєминах, які провокують конкуренцію та "закривають" розум учасників. Умовами відкритої міжособистісної взаємодії також $€$ можливість вільно висловлювати власні погляди, відкрито обговорювати інші точки зору, активне слухання, усвідомлення взаємної вигоди та особистісне прийняття [19]

Ребекка Мітчелл та Стівен Нікольс описують норми відкритості корпоративної культури у трьох вимірах: (1) переконання, що інші мають вільно висловлювати свої погляди, (2) рішучість пізнавати та визнавати цінність знань та цілей інших людей, (3) бажання використовувати найкращі ідеї, кому б вони не належали [12]

Джонатан Доні та Руперт Верегриф виокремлюють п'ять ключових аспектів особистісної відкритості під час взаємодії із представниками аут-груп: толерантність до неоднозначності; здатність зберегти самовпевненість, зустрівшись 3 інакшістю; наближення або уникнення під час зіткнення з інакшістю; ставлення до гіпотези "справедливого світу"; вплив навчального середовища.

Бренда Хаппел із співавторами досліджували ступінь стигматизації психічно хворих пацієнтів на вибірці студентів-медсестер з чотирьох країн (Австралії, Ірландії, Норвегії та Фінляндії) за трьома шкалами відкритості суджень: 1) наявність негативних настановлень до хвороби іншої людини; 2) готовність приховувати власну хворобу або навпаки, звертатися за допомогою; 3) соціальна дистанція із хворою людиною.

Отже, здійснені в рамках цього напряму дослідження показали зв'язок відкритості суджень зі (1) здатністю будувати продуктивні відносини з представниками аутгруп, (2) особистісною стійкістю до некомфортних ситуацій міжособистісної взаємодії, (3) нарощуванням потенціалу та підвищенням кваліфрікації для професій, які потребують високого рівня стресостійкості, (4) вирішення конфліктів [12, 13, 14, 19].

2. Когнітивна відкритість

Одна 3 найбільш відомих концепцій відкритості суджень належить Чарльзу Петерсону та Мартіну Селігману і є невід'ємною частиною теорії чеснот і сильних сторін характеру. Автори виділяють шість чеснот та сильних сторін характеру: 1) мудрість і знання, 2) сміливість, 3) людяність, 4) справедливість, 5) стриманість, 6) трансцендентність. Ці чесноти $€$ важливою передумовою досягнення сталого психологічного благополуччя. У рамках цієї теорії відкритість суджень $€$ одним з важливих проявів чесноти "мудрість і знання" разом із креативністю, цікавістю, прагненням до навчання. На думку Петерсона та Селігмана, відкритість це "... готовність активно шукати докази, що спростовують власні переконання, плани або цілі, і чесно розглядати такі докази, коли вони доступні" [15, с. 144].

Мімі Лорд описує відкритість суджень (ОРМ) у термінах критичного мислення або здатності до рефлексії, і вбачає в ній важливу передумову навчання [11]. Процес навчання в даному випадку розглядається як (1) отримання зворотного зв'язку через критичну переоцінку первісних суджень, рішень та помилок, (2) відкрите сприймання нових ідей. Вчена експериментально показує, що відкритість суджень позитивно впливає на здатність до навчання як на індивідуальному рівні, так і на рівні груп та організацій. Крім того відкритість суджень створює необхідні умови для покращення якості групових рішень через витіснення ефректів типу "групомислення" більш конструктивними процесами формування "спільного бачення" на основі вільного обміну думками. Отже, відкритість суджень впливає на групову динаміку, сприяє зменшенню впливу захисних механізмів, які дають змогу уникати отримання зворотного зв'язку від попередніх помилок або неприємної/загрозливої інфрормації i, тому, перешкоджають навчанню. Відкритість суджень змушує членів групи відкрито зіштовхуватися 3 конфрліктом, досліджувати непорозуміння та шукати взаєморозуміння, не вступаючи у боротьбу за владу. 
Команда індонезійських вчених провела експеримент із навчання студентів-математиків розв'язанню математичних задач на основі відкритого (open-minded) підходу. На відміну від стандартного алгоритму розв'язання задач, який передбачає постановку таких питань, як "що дано в задачі?", "про що питається?", "чи розв'язувала я подібні задачі раніше?" тощо, відкритий (openminded) підхід вимагає від студента шукати відповіді на запитання "чи можна зрозуміти умови задачі у різний спосіб?", "яких даних не вистачає в умовах задачі?" тощо. Після 14 тижнів експериментального навчання частина студентів на високому рівні оволоділа новим алгоритмом розв'язання математичних завдань, і мала змогу опціонально застосовувати його разом із традиційними алгоритмами. У даному випадку відкритість суджень трактувалася як складова критичного мислення разом із орієнтацією на факти, систематичністю, аналітичністю, впевненістю у собі, допитливістю та пізнавальною зрілістю. Отже, з перспективи даного дослідження відкритість суджень - це інтелектуальна навичка, яка спонукає студентів розглядати різні точки зору, щоб приймати об'єктивно обґрунтовані та зрілі рішення [6].

Ар'є Кругланські та Лорен Бояцці також дотримуються позиції про гнучкість когнітивних настановлень на відкритість або закритість суджень. На їхню думку, тут має йтися скоріш про різні режими сприймання нової інфрормації або інформації, що суперечить переконанням, які можуть активізовуватися у однієї й тієї самої людини під впливом певних обставин або залежно від конкретних цілей. Наприклад, перенасичення політичною інфрормацією може переводити людину до "закритого" когнітивного режиму, в якому вона більш не буде сприймати нічого нового. Також, стверджують автори, відкритість суджень іноді означає легковірність або відкритість до недостовірної інформації, що може негативно впливати на точність суджень чи якість прийнятих рішень [5].

Сачійо Ширман і Тімоті Левін визначають відкритість суджень "від протилежного", тобто через визначення "закритості суджень" або догматизму. Догматизм на їхню думку є особливістю когнітивного стилю, яка проявляється в індивідуальних способах відбору та обробки вхідної інформації. Вони запропонували компактний інструментарій для визначення індивідуального рівня догматизму, який буде використано у нашому дослідженні [17].

Отже, стислий огляд досліджень феномену відкритості суджень дозволяє зробити кілька попередніх висновків. По-перше, відкритість суджень визначає перебіг взаємодії особистості як з новими (або іншими) людьми, так і з новими (або іншими) ідеями. Обидва напрями $€$ важливими з погляду прийняття і схвалення соціальних нововведень, таких, як освітні інновації. Подруге, відкритість суджень інтерпретується водночас і як стала риса особистості або індивідуального стилю, і як навичка, що піддається розвитку або пригніченню.

Що стосується зв'язку відкритості суджень безпосередньо $з$ освітньою сферою, то тут йдеться по кілька напрямів наукової розробки цієї проблематики.

По-перше, відкритість суджень розглядається як необхідна передумова, і, водночас, як результат освіти. Йдеться, передовсім, про відкритість як готовність постійно переглядати власні погляди з урахуванням зустрічних доказів. У такому разі освіта $\epsilon$ процесом безперервного пошуку і прагнення до встановлення об'єктивної істини, у тому числі, у разі необхідності, кидаючи виклик усталеним традиціям, корпусу застарілих знань, світоглядним упередженням тощо [15]. Такий пошук має сприяти розвитку низки когнітивних навичок, що, у свою чергу, призводить до більшої відкритості суджень як загальної властивості освіченої людини.
Тобто, відкритість логічно пов'язана з концепцією освіти як такою [9].

По-друге, відкритість суджень аналізується у ролі педагогічної та/або освітньої практики. У цьому контексті відкритість розглядається як складова педагогічного стилю, яка дає змогу педагогові впроваджувати діалогові та інтерактивні практики навчання з метою підвищення ефективності навчання [там само]. Окремим завданням дослідники вважають передачу навички до відкритості суджень від педагога до учня в ході навчального процесу

Діалектика "мислення зростання" і "фріксованого мислення" у навчальному процесі, описана Керол Двек, певною мірою може бути синонімічною до проявів відкритості суджень в освіті. Мислення зростання, за задумом Двек, означає орієнтацію пізнавальної активності дитини на розвиток, де сама можливість розвитку виступає як самодостатнє позитивне підкріплення, i, як результат, сприяє більш глибокому та успішному засвоєнню знань, та більш спонтанним проявам креативних здібностей [8].

Нарешті, по-третє, відкритість суджень пов'язується із готовністю до сприймання інновацій як таких [7]. Водночас, бракує систематичних досліджень того, як відкритість суджень пов'язана з формуванням ставлення саме до освітніх інновацій, які є всеохоплюючими та універсальними, оскільки тією або іншою мірою зачіпають кожного громадянина.

Таким чином, метою статті $є$ дослідження ставлення громадськості до освітніх інновацій у контексті відкритості суджень, яка в даному випадку розглядається у двох аспектах: когнітивному (догматизм) та особистісному (відкритість новому досвіду).

Метод та результати дослідження

Дане дослідження спирається на розуміння відкритості суджень як сталого особистісного та когнітивного настановлення, а у ролі вимірювального інструментарію для визначення індивідуальних відмінностей за цим параметром обрано шкалу "Відкритість новому досвіду" п'ятифакторного опитувальника особистості Тірі (ТіріUkr) в українській адаптації та Шкалу догматизму за версією Сачійо Ширмана і Тімоті Левіна (Переклад українською здійснений автором статті і потребує подальшої верифрікації.) $[10,18]$. Ставлення до освітніх реформ вимірювалося за допомогою запитань, що використовуються у моніторингу громадської думки щодо проблем освіти та заходів з ії реформування ІСПП НАПН України (див. Додаток 1). Дослідження проводилося методом інтернет-анкетування на платформі 1 ka з 22 березня по 6 квітня 2020 року.

\section{Вибірка}

Було опитано 230 осіб (Частина анкет були заповненими не повністю, тому не враховувалися під час статистичного аналізу), з них 193 жінки та 37 чоловік. Вікова структура вибірки: до 18 років - 1\%; 18-29 років - 17\%, $30-58$ років - $78 \%$; понад 60 років - $4 \%$. $42 \%$ опитаних має дітей або онуків, які навчаються у закладах загальної середньої, $16 \%$ - вищої освіти. $48 \%$ опитаних працює у сфері освіти (Викривлення вибірки за соціальнодемографрічними показниками пов'язане зі способом просування онлайн-анкет переважно у професійних освітянських та педагогічних спільнотах в мережі Фейсбук).

В цілому серед респондентів переважає стримано песимістичний погляд на освітні реформи в Україні. Так, $51 \%$ опитаних вважають, що освітній рівень населення за роки незалежності знизився, $53 \%$ - що сучасна освітня система забезпечує переважно середній рівень освіти, $66 \%$ - що якісна освіта не є масово доступною для українців, $52 \%$ - що система освіти розвивається в 
невірному напрямі. Водночас, респонденті по-різному оцінюють окремі аспекти освітньої реформи. Запровадження 3НО схвалюють $73 \%$ учасників опитування, профрілізацію старшої школи - 89\%, введення 12-бальної системи оцінювання знань - 72\%. Думки щодо запровадження обов'язкового року передшкільного навчання з 5-річного віку розділилися майже навпіл: $45 \%$ схвалюють це нововведення, 45\% виступають проти. Найбільше неприйняття зафріксовано щодо 12-річного терміну навчання - 56\% висловили до цього негативне ставлення. Отже, можна говорити про неузгодженість або суперечливість оцінок респондентами реформ, що заплановані або вже здійснені в Україні.

Можна висунути принаймні три гіпотетичних причини такого стану громадської думки щодо освітніх реформ. Першою, і найбільш очевидною причиною може бути зміст і якість запропонованих урядом нововведень як таких, що $є$ об'єктивною підставою для формування негативного ставлення з боку громадськості. Друге гіпотетичне пояснення може критися в так званому "опорі непоінформованих" (49\% респондентів даного дослідження і 59,3\% респондентів всеукраїнського моніторингу громадської думки станом на вересень 2020 року вважають себе погано поінформованими про освітні реформи). Нарешті, по-третє, на уповільнене прийняття громадянами невідворотності реформ можуть впливати і суто психологічні фрактори.

\section{Виклад основного матеріалу дослідження}

Щоб перевірити першу і другу гіпотези дослідження, ми розділили вибірку на дві підгрупи. До першої підгрупи, яка охопила $48 \%$ загальної вибірки, увійшли респонденти, зайняті у ссрері освіти (підгрупа "освітяни"). До другої групи (52\% вибірки) увійшли респонденти, чия професійна діяльність жодним чином не пов'язана 3 освітою (підгрупа "не освітяни"). Можливість такого розподілу обумовлена припущенням, що судження щодо освітніх реформ тих респондентів, які краще поінформовані про освітні реформи, безпосередньо дотичні до усіх змін в освіті та опрацьовують ці зміни у своєму повсякденному досвіді, будуть максимально наближені до об'єктивних. Отже, якщо дизайн освітніх реформ об'єктивно $є$ недосконалим, між судженнями відносно краще поінформованих освітян і судженнями респондентів, які менше знають і розуміють про реформи, не мало б бути значущої різниці.

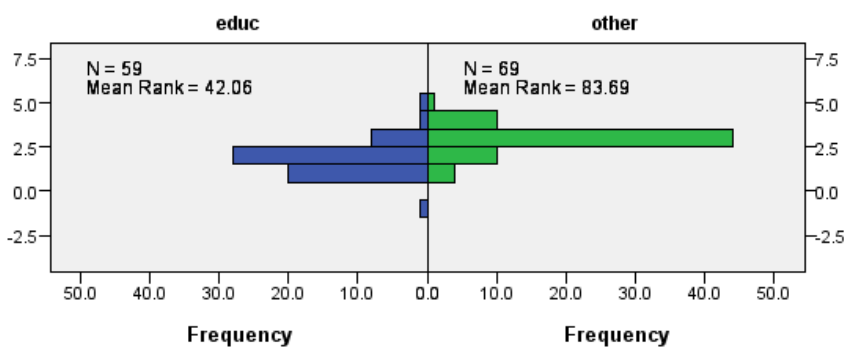

\begin{tabular}{|lr|}
\hline Total N & 128 \\
\hline Mann-Whitney U & 711.500 \\
\hline Wilcoxon W & $2,481.500$ \\
\hline Test Statistic & 711.500 \\
\hline Standard Error & 198.419 \\
\hline Standardized Test Statistic & -6.673 \\
\hline Asymptotic Sig. (2-sided test) & .000 \\
\hline
\end{tabular}

Рис. 1. Порівняння підгруп освітян і не освітян за рівнем поінформованості щодо реформ в освіті

Порівняння оцінок освітніх реформ загалом та їх окремих складових зокрема, які надають освітяни та не освітяни, за U-критерієм Манна-Вітні (Статистичний аналіз даних здійснювався за допомогою програмного забезпечення IBM SPSS Statistics 20) виявило значущі відмінності за двома змінними: рівнем поінформованості про реформи $(p=.001)$ та оцінкою ходу реформ освіти в України $(p=.000)$. Закономірно, що освітяни вважають себе в цілому більш поінформованими щодо змін, які відбуваються в освітній сфері, аніж респонденти, професійно не пов'язані з освітою (див. рис. 1).

Водночас у підгрупі респондентів-освітян частіше зустрічаються цілком або скоріше позитивні оцінки загального ходу освітніх реформ в Україні (див. рис 2).

Отже, оцінки освітніх реформ у респондентів, які профресійно дотичні і не дотичні до освіти та мають різний рівень поінформованості в цій сфері, розійшлися тільки у питанні загального курсу реформ. У той час як у ставленні до окремих аспектів освітніх інновацій значущих відмінностей між підгрупами освітян та не осві- тян не виявлено. Тобто першу і другу гіпотезу можна вважати такими, що підтверджуються лише частково і тому не пояснюють усіх випадків фрормування суперечливого ставлення громадськості до освітніх рефрорм.

Для перевірки "психологічної" гіпотези дані були піддані лінійному регресійному аналізу з урахуванням двох залежних змінних - рівня догматизму та рівня відкритості новому досвіду. Як незалежні змінні взято ставлення до освітніх реформ загалом та окремих їх складових зокрема.

Виявлені статистично значущі закономірності дають змогу заключити, що високий рівень догматизму респондентів пов'язаний з більш негативним оцінюванням освітніх реформ та їх здобутків. Зокрема, що вищим $€$ рівень догматизму, то вірогідніше респондент вважає, що загальний рівень освіти населення за роки незалежності України погіршився. Водночас, менш догматичним респондентам притаманна менша категоричність оцінок; вони частіше непевні щодо того, як змінилася вітчизняна система освіти і чи $є$ якісна освіта доступною для усіх громадян (табл. 1). 


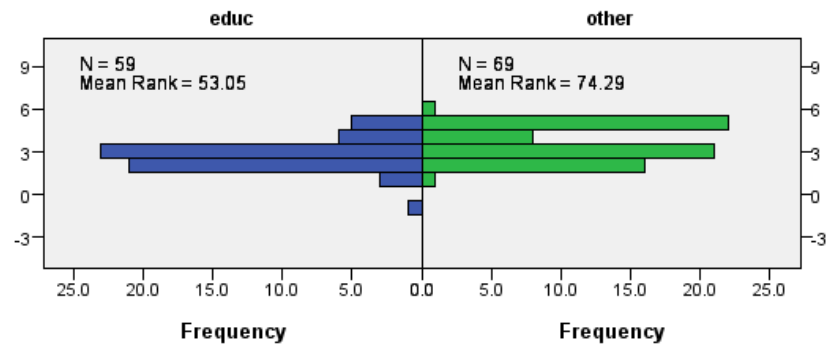

\begin{tabular}{|lr|}
\hline Total N & 128 \\
\hline Mann-Whitney U & $1,360.000$ \\
\hline Wilcoxon W & $3,130.000$ \\
\hline Test Statistic & $1,360.000$ \\
\hline Standard Error & 201.151 \\
\hline Standardized Test Statistic & -3.358 \\
\hline Asymptotic Sig. (2-sided test) & .001 \\
\hline
\end{tabular}

Рис. 2. Порівняння підгруп освітян та не освітян за модальністю оцінок ходу освітніх реформ

Оцінка освітніх реформ залежно від рівня догматизму (дані регресійного аналізу)

\begin{tabular}{|c|c|c|c|c|c|}
\hline \multicolumn{6}{|c|}{ Коефіцієнти } \\
\hline \multirow{3}{*}{ (Константа) } & \multicolumn{2}{|c|}{ Нестандартизовані } & \multirow{3}{*}{ Стандартизовані } & $\mathbf{t}$ & p \\
\hline & B & SE & & & \\
\hline & 65.438 & 2.995 & & 21.851 & .000 \\
\hline $\begin{array}{l}\text { Як, на Вашу думку, змінився за роки державної } \\
\text { незалежності України загальний освітній рівень } \\
\text { населення? }\end{array}$ & 1.911 & .913 & .233 & 2.094 & .039 \\
\hline $\begin{array}{l}\text { Як змінилася, на Вашу думку, за роки державної } \\
\text { незалежності України вітчизняна система освіти? }\end{array}$ & -1.905 & .832 & -.258 & -2.290 & .024 \\
\hline $\begin{array}{l}\text { Чи є доступною, на Вашу думку, для всіх громадян } \\
\text { України якісна освіта? }\end{array}$ & -2.322 & 1.019 & -.265 & -2.279 & .025 \\
\hline
\end{tabular}

Рівень відкритості новому досвіду виявився пов'язаним $з$ модальністю оцінок тих змін, які відбуваються в освітній сфері внаслідок реформ. Зокрема, респонденти з високим рівнем відкритості новому досвіду більш оптимістично оцінюють зміни у загальному освітньому рівні населення (табл. 2). Водночас більш відкриті громадяни сильніше впевнені у тому, що освіта потребує реформування, а також вважають себе в цілому краще поінформованими щодо освітніх реформ.

Оцінка освітніх реформ залежно від рівня відкритості новому досвіду (дані регресійного аналізу)

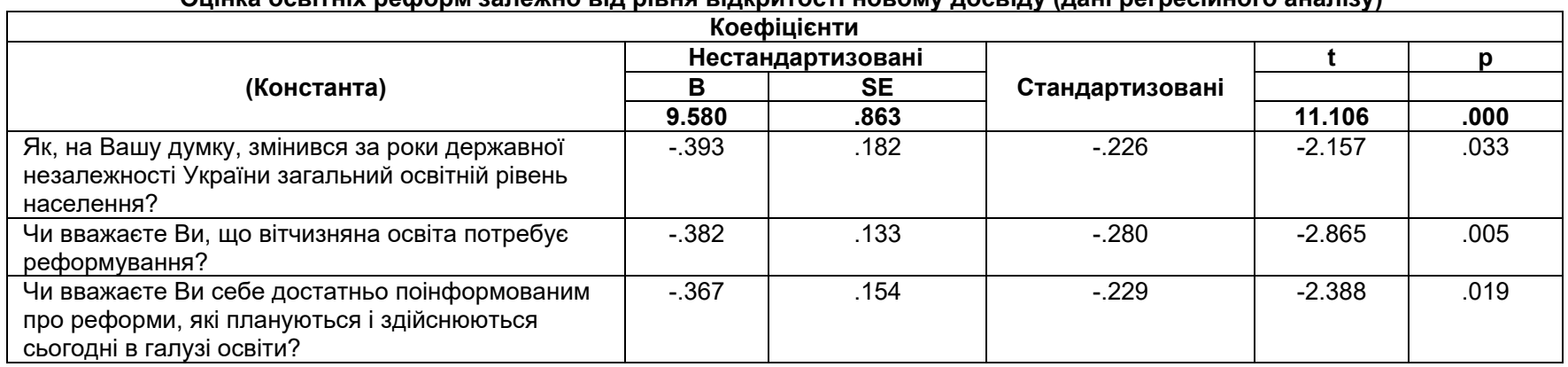

Далі ми здійснили додаткову перевірку "психологічної" гіпотези на підвибірках освітян і не освітян окремо. Для групи не освітян додатково виявлено значущий зв'язок між рівнем догматизму та оцінками того, чи потрібні реформи в освіті взагалі ( $p=.031)$. Таким чином, респонденти, професійно не пов'язані з освітньою сферою, то більше переконані у необхідності освітніх реформ, що менш догматичними та більш відкритими до нового досвіду вони є.
Однак набагато більш неочікуваними виявилися результати перевірки "психологічної" гіпотези для групи освітян, адже ставлення до освітніх реформ та їх окремих складових у цій підгрупі не показало значущих зв'язків ані з рівнем догматизму, ані зі відкритістю до нового досвіду.

Зрозуміло, що далекоглядних висновків 3 дослідження, що спирається на відповіді невеликої вибірку респондентів, робити жодним чином не слід. Однак дане дослідження дає змогу подивитися на формування ставлення громадськості до освітніх реформ як на 
багатовимірний процес, підпорядкований складній комбінації об'єктивних та суб'єктивних чинників.

\section{Обговорення результатів}

Соціально-психологічні дослідження проблематики ставлення громадськості до реформ в освіті, у тому числі здійснювані в рамках дослідно-експериментальної роботи за темою "Формування позитивної громадської думки щодо освітніх інновацій" (виконується Інститутом соціальної та політичної психології НАПН у 2016-2020 рр.) підтверджує психологічну обґрунтованість таргетованої роботи з громадською думкою. Кожна група, залучена до здійснення освітніх реформ або споживання їх результатів, має специфічні потреби, очікування та застереження. Зокрема, як показує дослідження О. Горової, психологічна готовність вчителів до впровадження освітніх реформ характеризується конфліктом між високою предметною компетентністю (когнітивний компонент) з одного боку, та недостатністю підготовки (інструментальний компонент), мінімальною ініціативою та зниженою мотивацією до залучення у процеси впровадження реформ (мотиваційний компонент) і пасивною, вичікувальною позицією (регуляційний компонент) з іншого [1]. Апробовані інтегративні технології збагачення громадської думки щодо освітніх реформ, наприклад Всеукраїнський конкурс-квест "Реформа - шлях до школи моєї мрії", дають змогу активізувати партнерські стосунки та налагодити творчу співпрацю між суб'єктами освітнього процесу: вчителями, учнями та батьками [4]. С. Іванченко виокремлює різні рівні здійснення соціально-психологічного супроводу освітніх рефрорм: загальносуспільний рівень, рівень окремих цільових груп (територіальних чи соціально-демографрічних спільнот, колективів конкретних організацій тощо), рівень окремих осіб [2]. Дослідницею обґрунтовано доцільність застосування таких методів соціально-психологічного супроводу освітніх реформ, як методи групової дискусії: метод знаходження консенсусу, технології надання повноважень, дослідження дією та ін. Водночас, соціальнопсихологічний супровід на рівні окремих осіб потребує додаткового пошуку механізмів та інструментів вивчення та впливу на суб'єктивне ставлення до реформ.

Отже, як було показано вище, притаманний особистості рівень догматизму та відкритості новому досвіду певною мірою пояснює ставлення до освітніх реформ загалом та окремих напрямів зокрема.

Догматизм пов'язаний з категоричністю оцінок щодо освітніх реформ загалом та їх здобутків. Зокрема, що вищим $\epsilon$ рівень догматизму, то вірогідніше респондент вважає, що загальний рівень освіти населення за роки незалежності України погіршився. Водночас, менш догматичним респондентам притаманна менша категоричність оцінок; вони частіше непевні щодо того, як змінилася внаслідок реформ вітчизняна система освіти і чи є якісна освіта доступною для усіх громадян.

Рівень відкритості новому досвіду виявився пов'язаним $з$ модальністю оцінок тих змін, які відбуваються в освітній сфрері внаслідок реформ. Зокрема, респонденти з високим рівнем відкритості новому досвіду більш оптимістично оцінюють зміни у загальному освітньому рівні населення. Водночас більш відкриті громадяни сильніше впевнені у тому, що освіта потребує реформування, а також вважають себе краще поінформованими щодо освітніх реформ

Результати дослідження також дають підстави стверджувати, що суб'єктивні, психологічні чинники відіграють помітно меншу роль у формуванні ставлення до освітніх реформ серед професіоналів, зайнятих в освітній сфері, у той час як для професійно не пов'язаних 3 освітою респондентів це досить роль психологічних чинників $є$ більш значущою.
Ці дані дають підстави поглиблювати дослідження феномену відкритості суджень (open-mindedness) на основі поєднання інструментів, що вимірюють когнітивні настановлення на догматизм та особистісні настановлення на відкритості новому досвіду.

\section{Висновки}

Дослідження проблеми суперечливого ставлення громадськості до освітніх реформ крізь призму відкритості суджень (open-mindedness) дало змогу виокремити специфічні чинники, що заважають або сприяють прийняттю нововведень представниками освітньої спільноти і громадянами, які професійно не пов'язані 3 освітою. Виокремлення когнітивного (догматизм) і особистісного (відкритість новому досвіду) аспектів відкритості суджень дозволило збудувати об'ємне бачення причин фрормування неоднозначного ставлення до реформ серед респондентів, що належать до різних груп.

На вибірці з 230 респондентів показано, що догматизм більше пов'язаний із категоричністю суджень щодо реформ в освіті, у той час як відкритість новому досвіду впливає на формування модальності оцінок реформ. Респонденти з вищим рівнем "відкритості" загалом позитивніше оцінюють зміни, ніж менш "відкриті", яким притаманний певний песимізм.

3'ясовано, що догматизм і відкритість новому досвіду по-різному проявляють себе у ставленні до освітніх реформ серед професіоналів, зайнятих в освітній сфреpi, і професійно не пов'язаних з освітою респондентів.

Суперечливе ставлення до освітніх реформ певною мірою пов'язано із рівнем поінформованості громадськості щодо проблем освіти та заходів з ії реформування. Посилення політики інформування в цій сфері сприятиме покращенню суспільного ставлення до освітніх реформ та підвищенню готовності до дієвого сприяння їх успішному впровадженню.

Краща поінформованість також може певною мірю впливати на пом'якшення догматичних настановлень або захистів щодо нової інформації.

Отже, планування офріційних інформаційнопросвітницьких кампаній щодо політики у сфері освітніх реформ має відбуватися з урахуванням потреб цільових аудиторій з різним рівнем поінформованості: менш поінформовані категорії громадян потребують інформації, більш обізнані - розвитку навичок взаємодії 3 цією інформацією. Тому подальші напрями дослідження мають фокусуватися на вивченні, розробці та апробації саме технологій взаємодії 3 інформацією, яка може входити в суперечність із системою суб'єктивних настановлень та переконань.

Додаток 1

Шкали вимірювання ставлення до освітніх реформ

Як змінився за роки державної незалежності України загальний освітній рівень населення?

1. підвищився

2. не зазнав суттєвих змін

3. знизився

4. важко відповісти

5. мені це байдуже

Як змінилася, на Вашу думку, за роки державної незалежності України вітчизняна система освіти?

1. зазнала кардинальних змін на краще

2. не зазнала суттєвих змін

3. зазнала змін на гірше

4. важко відповісти

5. мені це байдуже

Як Ви оцінюєте якість освіти, яку забезпечує сучасна українська освітня система?
1. висока
2. середня
3. низька
4. важко відповісти
5. мені це байдуже 
Чи є доступною, на Вашу думку, для всіх громадян України якісна освіта?

1. цілком так

2. скоріше так, ніж ні

3. скоріше ні, ніж так

4. зовсім ні

5. важко відповісти

6. мені це байдуже

Чи вважаєте $\mathrm{Bu}$, що вітчизняна система освіти розвивається у правильному напрямі?

1. цілком так

2. скоріше так, ніж ні

3. скоріше ні, ніж так

4. зовсім ні

5. важко відповісти

6. мені це байдуже

Чи вважаєте Bu, що вітчизняна освіта потребує реформування?

1. цілком так

2. скоріше так, ніж ні

3. скоріше ні, ніж так

4. зовсім ні

5. важко відповісти

6. мені це байдуже

Як Ви оцінюєте хід реформування системи освіти в

\section{Україні?}

1. цілком позитивно

2. скоріше позитивно

3. скоріше негативно

4. зовсім негативно

5. важко відповісти

6. мені це байдуже

Чи вважаєте Ви себе достатньо поінформованим про реформи, які плануються $і$ здійснюються сьогодні в галузі освіmu?

1. цілком так

2. скоріше так, ніж ні

3. скоріше ні, ніж так

4. зовсім ні

5. важко відповісти

6. мені це байдуже

Як Ви ставитеся до запровадження в Україні ЗНО - зовнішнього незалежного оцінювання знань випускників загальноосвітніх шкіл у формі тестування, результати якого $\epsilon$ підставою для зарахування до закладів вищої освіти?

1. позитивно

2. негативно

3. важко відповісти

4. не чув про таке

Як Ви ставитеся до профілізації старшої школи, що передбачає поділ учнів після дев'ятого класу для поглибленого вивчення окремих предметів або для набуття першої професії (поряд з отриманням повної загальної середньої освіти)?

1. позитивно

2. негативно

3. важко відповісти

4. не чув про таке

Як Ви ставитеся до запровадження в закладах загальної середньої освіти 12-річного терміну навчання?"

1. позитивно

2. негативно

3. важко відповісти

4. не чув про таке

Як Ви ставитесь до запровадження обов'язкового року передшкільного навчання для дошкільників 5-річного віку?

1. позитивно

2. негативно

3. важко відповісти

4. не чув про таке

Як Ви ставитесь до 12-бальної системи оцінювання знань, що використовується нині в закладах загальної середньої освіти?

1. позитивно

2. негативно

3. важко відповісти

4. не чув про таке
Список використаних джерел

1. Горова О. О. Методичні засади соціально-психологічного супроводу освітніх та суспільних реформ: емпіричне обґрунтування / О. О. Горова // Проблеми політичної психології. - 2017. - Вип. 6. С. 196-204. - Режим доступу: http://nbuv.gov.ua/UJRN/pppr_2017_6_19

2. Іванченко С.М. Методи соціальної взаємодії як складова соціально-психологічного супроводу освітніх та суспільних реформ / С.М. Іванченко // Проблеми політичної психології. Зб. наук. праць. - К., 2016. - Вип. 3 (17). - С.161-170.

3. Соціальна ситуація в Україні: особливості відображення трансформаційних процесів у громадській думці (2014-2018): довідник / Слюсаревський М.М., Гуменюк О.І., Дворник М.С., Черниш Л.П. - К.: Талком, 2019. -272 c.

4. Юрченко, В., \& Гриценок, Л. (2020). Вплив конкурсу-квесту на ставлення учасників освітнього процесу до реформи "Нова українська школа". Наукові студії із соціальної та політичної психології, (45(48), 110-120.

5. Arie W. Kruglanski \& Lauren M. Boyatzi (2012) The Psychology Of Closed And Open Mindedness, Rationality, And Democracy, Critical Review, 24:2, 217-232, DOI: 10.1080/08913811.2012.711023

6. As'ari, A.R., Kurniati, D., Abdullah, A.H., Muksar, M., \& Sudirman, S. (2019). Impact of Infusing Truth Seeking and Open-Minded Behaviors on Mathematical Problem-Solving. Journal for the Education of Gifted Young Scientists, 7(4), 1019-1036. DOI: http://dx.doi.org/10.17478/jegys.606031

7. Cegarra, J., Papa, A., Garcia-Perez, A., Fiano, F. An open-minded strategy towards eco-innovation: $A$ key to sustainable growth in a global enterprise / J. Cegarra at all// Technological Forecasting and Social Change. - 2019. - 148. - 119727. 10.1016/j.techfore.2019.119727.

8. Haimovitz, K. and Dweck, C.S. The Origins of Children's Growth and Fixed Mindsets / K. Haimovitz and C.S. Dweck// New Research and a New Proposal. Child Dev. - 2017. - 88. - P. 1849-1859. doi:10.1111/cdev.12955

9. Hare, W. Objections to open-mindedness in teaching. In OpenMindedness and Education. - McGill-Queen's University Press, 1979. from http://www.jstor.org/stable/j.ctt7zx21.10

10. Klimanska, M., \& Haletska, I. (2019). Ukrainain adaptation of the short five factor personality questionnaire tipi (tipi-ukr). Psychological journal, 5(9), 57-76. https://doi.org/10.31108/1.2019.5.9.4

11. Lord, M. (2015). Group learning capacity: The roles of openmindedness and shared vision. Frontiers in psychology. 6. 150. 10.3389/fpsyg.2015.00150.

12. Mitchell, R and Nicholas, S (2006) Knowledge Creation in Groups: The Value of Cognitive Diversity, Transactive Memory, and Openmindedness Norms. The Electronic Journal of Knowledge Management, Volume 4 Issue 1

13. Ole Boe et al (2015) Selecting the most relevant character strengths for Norwegian Army officers: An educational too. Procedia - Social and Behavioral Sciences, 197

14. Opykhailo O. B. (2014) Self-reported character strengths pertinent to gelotophobes, gelotophiles and katagelasticists. Вісник Дніпропетровського університету. Серія "Педагогіка і психологія ", 20.

15. Peterson, C., \& Seligman, M. E. P. (2004). Character strengths and virtues: $A$ handbook and classification. Washington, DC: American Psychological Association.

16. Robertson, L. H., Robertson, T. J., Robertson, D. T. The opened mind: An application of the historical concept of openness to education. In D. Conrad \& P. Prinsloo (Eds.), Open(ing) education: Theory and practice. Leiden, Netherlands: 2020. - https://doi.org/10.1163/9789004422988_003

17. Sawatzky, D \& Zingle, H. (1969). Accurate Interpersonal Perception and Open-mindedness. Perceptual and motor skills. 29. 395-400. 10.2466/pms.1969.29.2.395.

18. Shearman, Sachiyo \& Levine, Timothy (2006). Dogmatism Updated: A Scale Revision and Validation. Communication Quarterly. 54. 275-291. 10.1080/01463370600877950

19. Tjosvold, Dean; Poon, Margaret (1998). Dealing with scarce resources: openminded interaction for resolving budget conflicts. Group \& Organization Management. 23 (3).

\section{Refereces}

1. Horova O. O. Metodychni zasady sotsialno-psykholohichnoho suprovodu osvitnikh ta suspilnykh reform: empirychne obgruntuvannia / O. O. Horova // Problemy politychnoi psykholohii. - 2017. - Vyp. 6. - S. 196-204. - Rezhym dostupu: http://nbuv.gov.ua/UJRN/pppr_2017_6_19

2. Ivanchenko S.M. Metody sotsialnoi vzaiemodii yak skladova sotsialnopsykholohichnoho suprovodu osvitnikh ta suspilnykh reform / S.M. Ivanchenko // Problemy politychnoi psykholohii. Zb. nauk. prats. - K., 2016. - Vyp. 3 (17). - S.161-170.

3. Sotsialna sytuatsiia v Ukraini: osoblyvosti vidobrazhennia transformatsiinykh protsesiv u hromadskii dumtsi (2014-2018): dovidnyk / Sliusarevskyi M.M., Humeniuk O.I., Dvornyk M.S., Chernysh L.P. - K.: Talkom, 2019. - $272 \mathrm{~s}$.

4. lurchenko, V., \& Hrytsenok, L. (2020). Vplyv konkursu-kvestu na stavlennia uchasnykiv osvitnoho protsesu do reformy "Nova ukrainska shkola". Naukovi studii iz sotsialnoi ta politychnoi psykholohii, (45(48), 110-120

5. Arie W. Kruglanski \& Lauren M. Boyatzi (2012) The Psychology Of Closed And Open Mindedness, Rationality, And Democracy, Critical Review, 24:2, 217-232, DOI: 10.1080/08913811.2012.711023

6. As'ari, A.R., Kurniati, D., Abdullah, A.H., Muksar, M., \& Sudirman, S. (2019). Impact of Infusing Truth Seeking and Open-Minded Behaviors on 
Mathematical Problem-Solving. Journal for the Education of Gifted Young Scientists, 7(4), 1019-1036. DOI: http://dx.doi.org/10.17478/jegys.606031

7. Cegarra, J., Papa, A., Garcia-Perez, A., Fiano, F. An open-minded strategy towards eco-innovation: A key to sustainable growth in a global enterprise / J. Cegarra at all// Technological Forecasting and Social Change. - 2019. - 148. - 119727. 10.1016/j.techfore.2019.119727.

8. Haimovitz, K. and Dweck, C.S. The Origins of Children's Growth and Fixed Mindsets / K. Haimovitz and C.S. Dweck// New Research and a New Proposal. Child Dev. - 2017. - 88. - P. 1849-1859. doi:10.1111/cdev.12955

9. Hare, W. Objections to open-mindedness in teaching. In OpenMindedness and Education. - McGill-Queen's University Press, 1979. from http://www.jstor.org/stable/j.ctt7zx21.10

10. Klimanska, M., \& Haletska, I. (2019). Ukrainain adaptation of the short five factor personality questionnaire tipi (tipi-ukr). Psychological journal, 5(9), 57-76. https://doi.org/10.31108/1.2019.5.9.4

11. Lord, M. (2015). Group learning capacity: The roles of openmindedness and shared vision. Frontiers in psychology. 6. 150. 10.3389/fpsyg.2015.00150.

12. Mitchell, R and Nicholas, S (2006) Knowledge Creation in Groups: The Value of Cognitive Diversity, Transactive Memory, and Openmindedness Norms. The Electronic Journal of Knowledge Management, Volume 4 Issue 1
13. Ole Boe et al (2015) Selecting the most relevant character strengths for Norwegian Army officers: An educational too Procedia - Social and Behavioral Sciences, 197

14. Opykhailo O. B. (2014) Self-reported character strengths pertinent to gelotophobes, gelotophiles and katagelasticists. Вісник Дніпропетровського університету. Серія "Педагогіка і психологія ", 20.

15. Peterson, C., \& Seligman, M. E. P. (2004). Character strengths and virtues: A handbook and classification. Washington, DC: American Psychological Association.

16. Robertson, L. H., Robertson, T. J., Robertson, D. T. The opened mind: An application of the historical concept of openness to education. In D. Conrad \& P. Prinsloo (Eds.), Open(ing) education: Theory and practice. Leiden, Netherlands: 2020. - https://doi.org/10.1163/9789004422988_003

17. Sawatzky, D \& Zingle, H. (1969). Accurate Interpersonal Perception and Open-mindedness. Perceptual and motor skills. 29. 395-400. 10.2466/pms.1969.29.2.395.

18. Shearman, Sachiyo \& Levine, Timothy (2006). Dogmatism Updated: A Scale Revision and Validation. Communication Quarterly. 54. 275-291. 10.1080/01463370600877950.

19. Tjosvold, Dean; Poon, Margaret (1998). Dealing with scarce resources: openminded interaction for resolving budget conflicts. Group \& Organization Management. 23 (3)

Надійшла до редколегії 17.06.20

Рекомендована до друку 15.10.20

Svitlana Chunikhina, PhD (Psychology), Senior Researcher

Institute for Social and Political Psychology, NAES of Ukraine, Kyiv, Ukraine

\section{PUBLIC ATTITUDES TOWARD EDUCATIONAL REFORMS: A STUDY OF THE PROBLEM OF OPEN-MINDEDNESS}

The article reviews the problem of contradictory public attitude to educational reforms in connection with the phenomenon of openmindedness. Based on the review of case studies, two major areas of conceptualization of openness of judgments have been identified. The first direction studies the openness of judgments in the context of interpersonal interaction, as a lack of prejudice against members of groups that are interpreted as "others", willingness to tolerate "otherness" and productively interact with other people in conflict of opinions and positions. In the second direction, openness of judgment is seen primarily as a cognitive attitude to the perception of new ideas, tolerance of diversity of opinion and willingness to think outside the box ("out of box"). A sample of 230 respondents allowed to examine the relationship between cognitive (dogmatism) and personal (openness to new experiences) aspects of openness of judgment with a subjective attitude to educational reforms. Dogmatism is related to the tough judgments about educational reforms. More dogmatic respondents tend to have negative evaluations of reforms, less dogmatic ones are more likely to have no established evaluative judgments. Openness to new experiences determines the modality of assessments of educational reforms: more "open" respondents tend to be more positive about the changes that occur as a result of reforms than less "open" ones, which are characterized by a certain pessimism. It has been found that dogmatism and openness to new experiences manifest themselves in different ways in relation to educational reforms among professionals engaged in the field of education and non-professionally related to the education of respondents.

Keywords: openness of judgments, dogmatism, openness to new experiences, public attitude, educational reform

Bulletin of Taras Shevchenko National University of Kyiv. Series "Psychology". № 1(11), pp. 70-77 (2020)

УДК 159.923

DOI: https://doi.org/10.17721/BSP.2020.1(11).13
ISSN 1728-3817

(C) Taras Shevchenko National University of Kyiv,

Publishing and Polygraphic Center "Kyiv University", 2020

Ілля Ягіяєв, канд. психол. наук, асист. Аліна Новосельська, студ. Влада Келлер, студ. Марта Савич, студ.

Київского національного університету імені Тараса Шевченка, Київ, Україна

\section{ВИКОРИСТАННЯ СОЦІАЛЬНИХ МЕРЕЖ ТА СУБ'ЄКТИВНЕ БЛАГОПОЛУЧЧЯ В УМОВАХ ПАНДЕМІї COVID-19}

Актуальність теми пов'язана з психологічними наслідками пандемії COVID-19. Метою було дослідження суб'єктивного благополуччя на початку пандемії і запровадження карантинних заходів, та їхнього з6'язку з активністю у соціальних мережах. Використовувалися шкала позитивного та негативного афректу (Watson, Clark \& Tellegen, 1988), шкала задоволеності життям (SWLS) (Diener, Emmnos, Larsen, \& Griffin, 1985), шкала загальної самоефективності (Schwarzer \& Jerusalem, 1995), авторська анкета сприймання пандемії та уявлень про неї. Було визначено, що з суб'єктивним благополуччям під час пандемії пов'язані використання соціальних мереж, задоволеність життям, оцінка загрози для здоров'я та економічних наслідків, способи проведення вільного часу та рівень загальної самоефективності. Було здійснено якісний аналіз та визначено, що станом на початок епідемії в Україні у досліджуваних превалюють негативні прогнози наслідків епідемії та карантину. У лонгітюдній частині дослідження протягом місяця було виявлено зменшення рівня тривоги стосовно здоров'я, респонденти оцінювали загрозу своєму здоров'ю та економічні наслідки як менш серйозні, ніж на початку. Таким чином, загалом негативний афект у короткотривалій перспективі зменшився, особливо зменшились рівні страху та тривоги, проте рівень позитивного афекту не змінився.

Ключові слова: психологічне благополуччя, суб'єктивне благополуччя, пандемія, задоволеність життям, соціальні мережі, теорії змови, COVID-19.

Вступ. Пандемія COVID-19 стала серйозним випробуванням для людства у наші й так непевні та кризові для країни та світу загалом часи. Через пандемію COVID-19 у багатьох країнах світу було впроваджено карантин, що часто є неприємним досвідом для людей. Розлука з близькими, як і потреба постійно перебувати поряд із ними, втрата можливості вільного пересування, загальна непевність та нудьга можуть з часом спри- 